\title{
In Memory of Professor Gastón Guzmán (1932-2016)
}

\author{
Solomon P. Wasser \\ Department of Evolutionary and Environmental Biology and Institute of Evolution, Faculty of Natural Sciences, University \\ of Haifa, 199 Aba Khoushy Avenue, Mount Carmel, Haifa 3498838, Israel; spwasser@research.haifa.ac.il
}

On January 12, 2016, Professor Gastón Guzmán passed away. One can say without a doubt that Latin America has lost its greatest mycologist.*

I personally knew Professor Guzmán for many years. He was truly a great man admired by all who came to know him. I had just met with him last August at the Eighth International Medical Mushroom Conference in Manizales, where I had the pleasure of congratulating him on his birthday. Professor Guzmán was an outstanding scientific specialist in various aspects of mycology, including taxonomy, biodiversity, ecology, geography, ethnomycology, and the medicinal value of mushrooms, and he was respected worldwide.

Gastón Guzmán was born on August 26, 1932, in the city of Xalapa, Mexico. In 1951, he started his studies in biology at the National School of Biological Sciences, National Polytechnic Institute Mexico City. His interest in mycology began in 1955 when, as a graduate student, he decided to update the poorly maintained collection of fungi of the National Polytechnic Institute. During his first field work in the forests near Mexico City, he found a myriad of species about which little was known at the time. This inspired him to declare mushrooms as the topic of his thesis and he vowed to someday write a book on Mexican mushrooms.

In 1956, Guzmán met Dr. T. Herrera of the Institute of Biology of the National University of Mexico, the only mycologist at that time specializing in the macromycetes of Mexico. He formed a fruitful friendship with Dr. Herrera, which resulted in

\footnotetext{
*A special issue dedicated to Professor Guzmán's 50 years of mycological studies was published in 2006 (Int J Med Mushrooms. 2006;6:201-13), which included a list of his publications. In 2012, on his 80th birthday, another article devoted to G. Guzmán was published (Int J Med Mushrooms. 2012;14:529-34), in which the list of his publications from 2006 to 2012 was presented. Therefore, we include here only publications after 2012 .
}

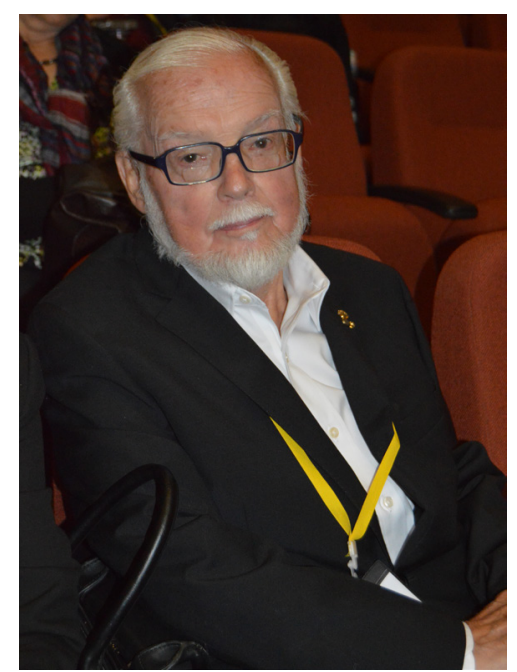

Professor G. Guzmán at the Eighth International Medicinal Mushrooms Conference (Manizales, Colombia, August 2015).

getting the field of mycology in Mexico up and running. In 1968, they founded the Mexican Society of Mycology, with Guzmán as the editor of the Society's bulletin, later the Society's journal, for 20 years.

In 1957, after reading R. Gordon Wasson's article "Seeking the Magic Mushroom," Guzmán was invited to go on an expedition to study neurotropic fungi in the Huautla de Jiménez region as an assistant to the most famous agaricologist of the second half of the 20th century, Professor Rolf Singer of the United States. As Guzmán has rightly said, Professor Singer was his first teacher of mycology, especially when it came to Agaricales s.l. On the last day of the expedition, he met R. Gordon Wasson from the United States, a world leader in the study of ethnomycology. This chance meeting resulted in a close friendship between the two men, which lasted for over 30 years. Years later, Guzmán met Professor Roger Heim from 
Paris, who was in Mexico with Wasson and Herrera studying the neurotropic fungi.

After accompanying Singer on his trips, Guzmán continued to explore the southeastern and central regions of the country on his own, collecting and studying hallucinogenic fungi, especially species of the genus Psilocybe, and collecting new ethnomycological data. In 1958, he published his first article on the ecology of Psilocybe, the genus previously studied separately by Heim and Singer and known under two different names. A year later, Guzmán published the first synopsis on the hallucinogenic fungi of Mexico with Singer and Heim.

In 1958, through his Indian contacts, Professor Guzmán learned about the Aztec word "teotlaquilnanacatl," which means "sacred mushroom" and is used by indigenous people to describe the hallucinogenic species of Psilocybe, rather than the word "teonanácatl," which is often cited in the literature (first by Schultes in 1939).

In 1959, Professor Guzmán presented his thesis on the taxonomy and ecology of Mexican hallucinogenic mushrooms and was awarded an Honorable Mention. Guzmán dedicated his thesis to his teacher Rolf Singer, as well as to Wasson, Heim, Schultes, and Teofilo Herrera, all of whom had helped him in conducting his research. He continued with his studies at the National Polytechnic Institute (19631968), pursuing a doctor of science degree, and spent some of that period (in 1965) studying under the supervision of Dr. Alexander H. Smith at the University of Michigan. In 1967, he presented his doctoral dissertation: "A Monograph of Species of the Genus Scleroderma on the American Continent," which was later published in Argentina in 1970 as a world monograph on that genus.

In 1970, Guzmán was awarded a scholarship by the Guggenheim Foundation of New York to carry out a worldwide study of the genus Psilocybe, with the goal of identifying hallucinogenic species and determining their distribution. Before this, in 1969 in Seattle, Guzmán met Dr. Richard Evan Schultes, with whom he previously had only correspondence, in a piano bar. Later, Schultes would send Guzmán information from the Guggenheim Foundation to apply for a scholarship and it was with this scholarship that Guzmán carried out his research in South America, the United States, Europe, and Japan. This allowed him to publish a world monograph on the genus Psilocybe in 1983. In 1995, he published a supplement to that monograph (Guzmán, 1995) and he was preparing the second edition of the monograph at the time of his death.

Among Professor Guzmán's main contributions to mycology in Latin America were his tireless work, his exploration, and his established collections of fungi. Guzmán was the one who organized the first mushroom fair in Mexico in 1977 and later organized more than 100 mushroom fairs in the country, as well as in Guatemala, Panama, and Colombia. In 1955, he founded the Mushroom Collection of the National School of Biological Sciences (ENCB), which exceeds 120,000 specimens and is currently the largest in Mexico. In 1982, he was invited to work at the National Institute for Research on Biotic Resources in Xalapa, Veracuz, where he initiated what is now the second largest collection of fungi in Mexico. This collection (XAL) is currently under stewardship of the Institute of Ecology, A.C., and houses more than 55,000 specimens. Guzmán has contributed to the different mushroom collections maintained by institutions in Mexico and Latin America, as well as to the training of their collectors and curators. Guzmán's passion for field work led him to collect and record more than 41,000 mushroom specimens from all over the world, and these are deposited in ENCB and XAL with some duplicates in IBUG and MEXU, as well as other herbaria in the United States and Europe.

Professor Guzmán was a consummate teacher and was always concerned about training young people with strict scientific rigor and an enormous sense of discipline. Throughout his professional life, he set up and encouraged many research teams in Mexico. He supervised more than 200 theses dealing with different aspects of mycology. Mexican mycologists such as Nahara Ayala, Víctor Bandala, Santiago Chacón, Joaquín Cifuentes, Alonso Cortés-Pérez, Laura Guzmán-Dávalos, José Marmolejo, Daniel Martínez-Carrera, Gerardo Mata, Rosario Medel, Leticia Montoya, Florencia Ramírez-Guillén, Dulce Salmones, Ricardo Valenzuela, and Luis Villarreal, 
among others, have been Guzmán's students. Although his influence in different national and international institutions was significant, the research team that best demonstrated his leadership in the field of mycology was the group that he brought together in Xalapa, where he was living and working.

In 1990, on the initiative of Guzmán, the Latin America Association of Mycology was founded in Havana, Cuba. Since its creation, this organization has played a very important role in the field. There have been two conferences in Havana (1993 and 1996) and one in Caracas (1999). In 2002, with Guzmán as its president, the fourth conference was held in Xalapa. Later, in 2005, the Fifth Latin American Mycology Conference was held in Brasilia, Brazil. In 2008, the conference took place in Argentina and the last one was held in Costa Rica.

Professor Guzmán was an honorary member of the Mexican Society of Mycology, the Botany Society of Mexico, the Latin American Association of Mycology, the Academy of Sciences of Colombia, the Baracaldo Mycological Society (Spain), and the Mycological Society of America.

In 2002, the National University of Mexico (UNAM) carried out a study (Michan-Aguirre and Llorente, 2003) to determine which Mexican scientist had published the most in taxonomy during the 20th century. Guzmán came in second, after one zoology professor, indicating that, in the last century, he was the most important taxonomist in mycology in Mexico. Throughout his extensive career, from 1958 to 2016, Guzmán published more than 400 scientific articles, 16 books, and more than 30 book chapters. Among his most important works, in addition to the book on Psilocybe, were its supplement, the monograph on Scleroderma, and The Identification of Mushrooms, which was published in 1977. This book was the first to be published in Mexico on macroscopic fungi and continues to be used as a basic text wherever mycology is taught in Mexico. It is also a reference work for Latin American mycologists. Another important book, The Cultivation of Edible Mushrooms, was published in collaboration with several of his students. This was a pioneering effort in Mexico and was very well accepted. Also noteworthy is the book, The Name of
Mushrooms and Related Things in Latin America, which has been acclaimed internationally as an encyclopedia of mushrooms. Guzmán described more than 200 new taxa (genera and species) for Mexico and other parts of the world. This enormous diversity both in the fields of his studies and in the groups of mushrooms that he was investigating resulted in his publications being cited more than 3000 times in books and journals all over the world. More than half of the known species belonging to the genus Psilocybe were described by Guzmán.

Guzmán was a member of the Editorial Board of the International Journal of Medicinal Mushrooms for 17 years, right from its onset in 1999. He was a very diligent and creative reviewer and the author of many very important papers. He took part in all of the International Medicinal Mushrooms Conferences since the first one was held in 2001 in Kiev (Ukraine).

A cofounder and former president of the Mexican Mycological Society, he also served as president of the Latin American Mycological Association (2000-2002) and was a founding member of the Panamanian Mycological Society. In his later years, Guzmán held an emeritus research chair at the Ecological Institute of Xalapa, where he founded the Department and Herbarium of Fungi. Guzmán has organized interesting scientific lectures and mycological expositions, was engaged in teaching, and prepared articles and books, not only in Mexico, but also outside of the country. He was also a guide on Mexican mushroom tours.

In 2001, Guzmán went to a meeting in Nepal, where he explored part of the country collecting interesting mushrooms, publishing in 2010 an article with his student F. Ramírez-Guillén. In 2010, Guzmán explored the surrounding area of the Research Center of Fungi in Thailand, where he found five new species of the genus Psilocybe (Guzmán et al., 2012) and several other interesting mushrooms. He also gave lectures and presentations in Nepal, Thailand, and Malaysia.

The diversity of Professor Guzmán's research programs, his scientific, organizational, and pedagogical activities, along with his significant achievements in fungal taxonomy and other fields of mycology, reveal him as a scientist of many 
interests, a brilliant science organizer, and a world scientific leader of the School of Mushroom Biology, the achievements and accomplishments of which became incorporated into the world of science.

Professor Guzmán was an extraordinary, vibrant man in the broadest sense of the word. Apart from his scientific activities, Guzmán also enjoyed romantic music, bohemia, and poetry-he even wrote poems related to love, life, and women. He was married twice and has three daughters from his first marriage, among them Laura Guzmán-Dávalos, an outstanding mycologist at the University of Guadalajara in Mexico.

Guzmán attracted people like a magnet because of his charm, wit, and erudition. From the first encounter with him, you sensed the warmth of his personality and his outgoing, unconventional nature. He was not only a creative and gifted scientist, but he was also an intellectual with a broad education. In 2012, he celebrated his 80th birthday at the peak of his creative activity.

One of his last articles, entitled "New Studies on Hallucinogenic Mushrooms: History, Diversity, and Applications in Psychiatry" was published in issue 11 of the International Journal of Medicinal Mushrooms (Guzmán, 2015).

For his knowledge, professionalism, dedication, diligence, and warm personality, colleagues and friends of Professor Guzmán will certainly agree with me that he will be dearly missed.

\section{LIST OF PUBLICATIONS OF GASTÓN GUZMÁN: 2012-2016}

\section{Articles}

Guzmán G. New taxonomical and ethnomycological observations on Psilocybe s.s. (Fungi, Basidiomycota, Agaricomycetidae, Agaricales, Strophariaceae) from Mexico, Africa and Spain. Acta Botanica Mexicana. 2012;100:81-108.

Ramírez-Cruz V, Guzmán G, Guzmán-Dávalos L. New combinations in the genus Deconica (Fungi, Basidiomycota, Agaricales). Sydowia 2012;64:217-9.

Camacho-Sánchez M, Guzmán G, Guzmán-Dávalos L. Pleurotus opuntiae (Durieu et Lév.) Sacc. (higher Basidiomycetes) and other species related to Agave and Opuntia plants in Mexico: taxonomy, distribution, and applications. Int J Med Mushrooms. 2012;14:65-78.
Guzmán G, Ramírez-Guillén F, Hyde K.D., Karunarathna SC. Psilocybe s.s. in Thailand: four new species and a review of previously recorded species. Mycotaxon. 2012;119: 65-81.

Guzmán G, Guzmán-Dávalos L. La maestra Luz María Villarreal de Puga y la Micología de Jalisco, México. Ibugana. 2013;4:89-95.

Guzmán G, Cortés-Pérez JA, Ramírez-Guillén F. The Japanese hallucinogenic mushrooms Psilocybe and a new synonym of P. subcaerulipes with three Asiatic species belong to Section Zapotecorum (Higher Basidiomycetes). Int J Med Mushrooms. 2013;15:607-15.

Ramírez-Cruz V, Guzmán G, Guzmán-Dávalos L. Type studies of Psilocybe sensu lato (Strophariaceae, Agaricales). Sydowia. 2013;65:277-319.

Guzmán G, Cortés-Pérez JA, Guzmán-Dávalos L, RamírezGuillén F, Sánchez-Jácome MR. An emendation of Scleroderma, new records, and review of the known species in Mexico. Revista Mexicana de Biodiversidad. 2013;84(Suppl):173-91.

Ramírez-Cruz V, Guzmán G, Villalobos-Arámbula AR, Rodríguez A, Matheny PB, Sánchez-García M, GuzmánDávalos L. Phylogenetic inference and trait evolution of the psychedelic mushroom genus Psilocybe sensu lato (Agaricales). Botany. 2013;91:573-591.

Santos da Silva P, Ramírez-Cruz V, Cortés-Pérez JA, Guzmán G, Guzmán-Dávalos L, Borges da Silveira RM. Deconica neorhombispora (Agaricales, Strophariaceae): new combination and synonym. Sydowia. 2013;65:321-8.

Gándara E, Guzmán-Dávalos L, Guzmán G, Rodríguez O. Inventario micobiótico de la región de Tapalpa, Jalisco, México. Acta Botanica Mexicana. 2014;107:165-185.

Guzmán G. Análisis del conocimiento de los hongos sagrados entre los mazatecos después de 54 años. Etnoecológica. 2014;10:1-16.

Cortés-Pérez A, Guzmán G, Ramírez-Guillén F. Squamanita umbonata (Fungi, Agaricales, Tricholomataceae), primer registro en México. Acta Botanica Mexicana. 2014;108:105-11.

Guzmán G, Nixon SC, Ramírez-Guillén F, Cortés-Pérez A. Psilocybe s. str. (Agaricales, Strophariaceae) in Africa description of a new species from the Congo. Sydowia. 2014;66:43-53.

Cortés-Pérez JA, Ramírez-Guillén F, Guzmán G. Nuevos registros de Mycena Sección Sacchariferae (Basidiomycota) para México. Revista Mexicana de Micología. 2015;41: $77-85$.

Pérez-Pérez RE, Guzmán G. Parmotrema species in a cloud forests region turned into an urban zone in Xalapa, Veracruz, Mexico. Bosque. 2015;36:357-62.

Trejo Aguilar D, Guzmán G, Lara L, Zulueta RR, Palenzuela J, Sánchez-Castro I, Alves da Silva G, Sieverding E, Oehl F. Morphology and phylogeny of Acaulospora foveata (Glomeromycetes) from Mexico. Sydowia. 2015;67: 119-26. 
Guzmán G. New studies on hallucinogenic mushrooms: history, diversity, and applications in psychiatry. Int J Med Mushrooms. 2015;17:1019-29.

Guzmán G. Las relaciones de los hongos sagrados con el hombre a través del tiempo. Anales de Antropología. 2016;50: 134-47.

Sommerkamp Y, Paz AM, Guzmán G. Medicinal mushrooms in Guatemala. Int J Med Mushrooms. 2016;18:56-64.

\section{Books}

Guzmán G. Devastación de los bosques y selvas en México. La urgencia de su conservación. Xalapa (Mexico): INECOL; 2013.

\section{Book Chapters}

Guzmán G. 2012. Los hongos alucinógenos y su acción sobre el sistema nervioso central. In: Méndez-Tovar LJ,
López-Martínez R, Hernández-Hernández F, editors. Actualidades en Micología Médica. Sefirot, S.A. de C.V. y UNAM. p. 256-60.

Guzmán G. 2013. Sacred mushrooms and man: Diversity and traditions in the world, with special reference to Psilocybe. In: Rush JA, editor. Entheogens and the development of culture. North Atlantic Books. p. 485-518.

Guzmán G. 2014. El uso tradicional de los hongos sagrados: pasado y presente. In: Moreno Fuentes A, Garibay Orijel R, editors. La Etnomicología en México. Estado del Arte. Red de Etnoecología y Patrimonio Biocultural (CONACyT), Universidad Autónoma de Estado de Hidalgo, Instituto de Biología (UNAM), Sociedad Mexicana de Micología, Asociación Etnobiológica Mexicana, A.C. p. 61-88.

Guzmán G. 2015. La micología médica en las culturas indígenas pre- y post la conquista. In: López-Martínez R, editor. Historia de la Micología Médica en México. Academia Mexicana de Dermatología, A.C. p. 17-35. 